\section{[continued from page 32]}

NeHRing, A. (1902). Mustela fonia syriaca from Jordan. Sitzber Ges. Naturf. Fr. Berlin, p. 145.

Nelson, B. (1973). Azraq Desert Oasis. Allen Lane, London, England, UK: xix +436 pp., illustr.

PAZ, U. (1982). The fauna of the Holy Land at the end of the Ottoman period. Isr. Land and Nat. Spring, 1982, pp. 104-10.

PERKINS, D., jun. (1966). The fauna from the Madamagh and the Beidha. Palestine Exploration Quarterly, Five Seasons at the Beidha, Appendix B, pp. 66-7.

PERKINS, D., jun. (1968). The Pleistocene fauna from the Yabrud Rockshelters. Annales Archeologiques Arabe Syrienne, 18, pp. 123-30.

PontiCELLI, S.C. (1979). Testimonianze neolitiche nel deserto della Giordana meridimale Estratto da'. Studi Per Ecologia del Quaternario [not available for checking].

PoR, F. (1987). The Levantine landbridge: historical and present patterns. Pp. 23-8 in Proceeding of the Symposium on the Fauna and Zoogeography of the Middle East, Mainz 1985 (Eds F. KRUPP, W. SCHNEIDER \& R. KINZELbaCH). Beihefte Zum TAVO A 28: pp. 23-8.

QUMSIYEH, M.B. (1980). New records of bats from Jordan. Saugetierk. Mitt., 28, pp. 36-9.

QumsiYeH, M.B. (1985). The Bats of Egypt. Special Publ., Museum Texas Tech. Univ., No. 23, 102 pp., illustr.

Qumsiyeh, M.B., SchlitTer, D. A. \& Disi, A.M. (1986). New records and karyotypes of small mammals from Jordan. Sonderdruck aus Z.F. Saugetierk Bed., 51, pp. 139-46.

SEARIGHT, A. (1987). Some records of mammals from north-eastern Jordan. Proceedings of the Symposium on the Fauna and Zoogeography of the Middle East Mainz, 1985 (Eds F. KRUPP, W. SCHNEIDER, \& R. KINZELbACH). Beihefte Zum TAVO A 28 , pp. 311-7.

Short Communications and Reports [continued from page 74]

Grassl, H. (1989). Wolkenbilding und Flugzeuge. Pp. 69-107 and 166-67 in Unheil über unseren Köpfen? (Ed. M. PFEIFFER \& M FISCHER). Quell-Verlag, Stuttgart, Germany: 239 pp., illustr.

Grassl, H. (1990). Possible climatic effects of contrails and additional water vapor. Pp. 124-37 in Air Traffic and the Environment (Ed. U. SchumanN), Springer Verlag, Berlin \& Heidelberg, Germany: 170 pp., illustr.

Grassl, H. \& Klingholz, R. (1990). Wir Klimamacher. S. FischerVerlag, Frankfurt, Germany: 296 pp., illustr.

IEA (International Energy Agency) (1990). Oil and Gas Information 1987-1989. IEA, 2 Rue André Pascal, 75775 Paris, Cedex 16, France: 602 pp., illustr.

JOHNSTON, H.S., KinNisOn, D.E. \& WuEBbLES, D.J. (1989), Nitrogen oxide from high-altitude aircraft, an update of potential effects on ozone. Journal of Geophys. Research, 94, pp. 16,351-63, illustr.
TALBOT, L.M. (1960). A look at threatened species: A report on some animals of the Middle East and Southern Asia which are threatened with extermination. Oryx, 5, pp. 153-293.

Thomas, O. (1892). On Gerbillus calurus from Sinai and Meriones tristami from Palestine. Ann. Mag. Nat. Hist., 6(9), pp. 76-148.

Thомаs, O. (1917). A new vole from Palestine [Microtus philistinus, a form of Gunther's Vole]. Ann. Mag. Nat. Hist., 19(8), pp. 450-1.

Thomas, O. (1919a). The White-toothed shrew of Palestine. Ann. Mag. Nat. Hist., 9(3), p. 32 [describes Crocidura russula judaica].

Thomas, O. (1919b). Two new gerbils from Sinai. Ann. Mag. Nat. Hist., 9(3), pp. 559-60.

Thomas, O. (1922a). The forms of Jaculus jaculus in Egypt and Syria. Ann. Mag. Nat. Hist., 9(9), pp. 295-7.

Thомаs, O. (1922b). A new jird (Meriones) from Palestine. Ann. Mag. Nat. Hist., 9(10), pp. 552-3.

TOQUAN, F. (1979). Al-Haar: A Research in the Ummayad Palaces in The Badia. Dar Al-Shab Press and Ministry of Culture and Youth, Amman, Jordan: 551 pp., illustr.

Tristram, H.B. (1866). Report on the mammals of Palestine. Proc. Zool. Soc. London, 1866, pp. 84-93.

Tristram, H.B. (1884). The Survey of Western Palestine, The Fauna and Flora of Palestine. Pub, by the Committee of the Palestine Exploration Fund, London, England, UK: pp. 1-30.

VAUfREY, R. (1951). Mammiferes. Pp. 198-217 in Le Paleolithique Mesolithique du désert de Judée (Ed. R. Neuville). Archives Institute Paleontologie Humaine, 24.

WASSIF, K. (1954). On a collection of the mammals from northern Sinai. Bull. Inst. Desert d'Egypt, 3(1), pp. 107-18.

ZAYADINE, F. (1977). The Frescos of Qusier Amra. Department of Antiquities of Jordan, Amman, Jordan: 14 pp. +21 figs.

KaVAnaugh, M. (1988). New Estimates of $N O_{x}$ from Aircraft: 1975-2025. 81st Annual Meeting of APCA, the Association Dedicated to Air Pollution Control and Hazardous Waste Management, Pittsburgh, USA: 1-15 pp., illustr.

LIOU, K.N., OU, S.C. \& KOENIG, G. (1990). An investigation of the climatic effect of contrail cirrus. Pp. 154-69, in Air Traffic and the Environment (Ed. U. SCHUMANN). Springer Verlag, Berlin \& Heidelberg, Germany: 170 pp., illustr.

RudLOFF, H. vON (1988). Luft- und Raumfahrt als Ozonkiller Raum und Zeit, 37, pp. 22-36, illustr.

Wuebbles, D.J. \& KinNison, D.E. (1990). Sensitivity of stratospheric ozone to present and possible future aircraft emissions. Pp. 107-23 in Air Traffic and the Environment (Ed. U. SCHUMANN). Springer Verlag, Berlin \& Heidelberg, Germany: $170 \mathrm{pp}$. , illustr.

ROBERT A. EGLI

Chemist and Air Pollution Consultant Etzelstrasse 15

CH-8200 Schaffhausen

Switzerland.

Notes, News \& Comments [continued from page 80]

\title{
Convention on Damage Caused to the Environment
}

A convention on damage resulting from activities that prove dangerous to the environment is being prepared by the Council of Europe, in response to the need to propose measures to compensate victims of damage to the environment. To date, such problems have received scant attention at any international level - with the exception of specific issues such as nuclear energy or the transport of goods.

In addition to providing for suitable compensation, the Convention will offer the bases of means to prevent environmental damage and of those to rehabilitate impaired sites. Provision will also be made for access to pertinent information - particularly information that held by public authorities or industrial operators.

DIRECTORATE OF LEGAL AFFAIRS
Council of Europe
Boite Postale 431 R6
F-67006 Strasbourg Cedex
France.

DiRECTORATE OF LEGAL AFFAIRS

Council of Europe

F-67006 Strasbourg Cedex

France. 